\title{
Dissonances between Teachers' Beliefs and Practices of Formative Assessment in EFL Classes
}

\author{
Ida Ayu Made Sri Widiastuti
}

Universitas Negeri Malang, Indonesia, idaayuwidia@unmas.ac.id

\section{Nur Mukminatien}

English Language Teaching, Universitas Negeri Malang, Indonesia, nur.mukminatien.fs@um.ac.id

\section{Johannes Ananto Prayogo}

English Language Teaching, Universitas Negeri Malang, Indonesia, johannes.ananto.fs@um.ac.id

\section{Enny Irawati}

English Language Teaching, Universitas Negeri Malang, Indonesia, enny.irawati.fs@um.ac.id

\begin{abstract}
This qualitative study investigates multi-cases of junior high school English teachers to reveal the dissonances between teachers' beliefs and practices of formative assessment in EFL classes viewed from different Continuing Professional Development (CPD). The Data were collected by conducting semistructured interviews to all respondents, classroom observations and document studies such as journals and lesson plans. The result of this study showed that teachers with high CPD participation level have stronger beliefs in formative assessment compared to those with lower CPD involvement. Their beliefs, however, were not always practiced appropriately in the classroom. Teachers' CPD participation has no real impact on the success of formative assessment practices, although it may influence teachers' beliefs. This is due to some factors influenced the implementation of formative assessment in the classroom. Futhermore, it is expected that teachers carefully consider the influecing factors and carry out formative assessment in accordance with their beliefs.
\end{abstract}

Keywords: formative assessment, dissonance, belief, practice, teachers, EFL

\section{INTRODUCTION}

In recent decades, classroom assessment has gained more serious attention in education because it helps teachers improve the quality of learning. Therefore, in both local and 
global contexts, researchers and practitioners have tried to discover appropriate and efficient assessment methods for measuring and monitoring students' progress in learning. Assessment is conducted to identify the success of learning, and it provides information about students' abilities that can be used as a basis to enhance learning to achieve instructional goals (Stiggins, 2002; Pantiwati, \& Husamah, 2017). As a part of teaching and learning, assessment becomes a procedure used by teachers to find out their students' level of knowledge and skills, learning outcomes, the strengths, and weaknesses, so that they can motivate them to improve their abilities. Additionally, the assessment makes teachers provide corrective feedback on what students are learning, how much learning material can be understood, and how well students learned (Box, Skoog, \& Dabbs, 2015). The aims of classroom assessment are not only explicitly intended to determine the weaknesses and success of the students, but also to figure out the ways of improving the quality of students learning (Birenbaum, Kimron, \& Shilton, 2011; Ashraf, \& Zolfaghari, 2018). In English language teaching, all skills: listening, speaking, reading and writing should be thoroughly assessed by the teacher.

Recently, researchers found that there are two main categories of assessment used by the teachers. They are summative assessment and formative assessment. Summative assessment is a procedure to make a judgment or to summarize all the evidence up to a given point of the students' achievement, or what a student has grasped at the end of a course or unit of instruction. This kind of assessment is often called an assessment of learning (Clark, 2012; Stiggins, 2002). The second type of assessment is formative assessment or assessment for learning (Derrick \& Ecclestone, 2006; Stiggins, 2002). In English language learning, formative assessment is generally focused on helping the students to improve their language competence, to identify the learning improvement and achievement, and to detect students' needs. In contrast, formative assessment is embedded in the teaching and learning process used to adapt the teaching strategies/techniques to meet educational needs and standards (Black \& Wiliam, 2009; Rivai, Ridwan, Supriyati, \& Rahmawati, 2019). The focus of the assessment is to identify the problems faced by the students in learning and help them improve their knowledge and skills. Teachers are expected to make and give appropriate types of assessment to measure students' competence.

Theoretically, the implementation of the formative assessment is related to the teachers' knowledge and beliefs about the notion of formative assessment. A strong belief about formative assessment is a result of having a good understanding of the benefits of conducting a formative assessment (Clark, 2012; Coffey, Hammer, Levin, \& Grant, 2011). The way teachers carry out a formative assessment is strongly influenced by their beliefs (Leung \& Scott, 2009) and also how they make decisions about students' learning outcomes are strongly influenced by their belief in assessment practices (Derrick \& Ecclestone, 2006; Karimi \& Shafiee, 2014; Kuze \& Shumba, 2011). So, in short, having good knowledge and skills about assessment would be predicted to influence to carry out it appropriately. It can be said that the teacher's belief in formative assessment has a significant influence on the way teachers conduct the assessment. Those who have a high belief of formative assessment benefits are more likely to carry out formative assessment properly (Karim, 2015). 
Preliminary studies which were conducted to the EFL teachers revealed that the success and failure of formative assessment practice are influenced by the teacher's belief in formative assessment (Borg, 2011; Guadu \& Boersma, 2018; Karim, 2015; Quyen \& Khairani, 2016). Additionally, classroom observation conducted to the teachers to see the links between the results of the interviews showed that the implementation of formative assessment is not always consistent with teachers' beliefs. Some teachers believe that formative assessment is beneficial for identifying students' difficulties in learning English. They also believe that assessment results can be used to modify teaching strategies to meet learning objectives. Some of them, however, did not use formative assessment results correctly, and the follow-up actions were not carried out properly. These indicated that teachers did not intensively do as what they believed. Therefore to be effective, teachers need further training including guidelines revision, monitoring and periodic evaluation (Yahiji, Otaya, \& Anwar, 2019).

A study conducted by Black \& Wiliam (2009) found that several factors influenced the practices of formative assessment. However, others studies have indicated that formative assessment practices are influenced by teacher's beliefs (e.g., Guadu \& Boersma, 2018; Karim, 2015; Kuzborska, 2011; Quyen \& Khairani, 2016). It is still necessary to ascertain how teachers' beliefs can significantly affect their practice in English classes. However, there are English teachers who did not correctly carry out the formative assessment due to some influencing factors occurred. Given the phenomenon as described above, therefore this study focuses on understanding the contextual factors that explain teachers' beliefs about formative assessment and why teachers' beliefs on formative assessment in English classes are not always the same as their implementation.

Each teacher has different beliefs and practices on formative assessment. Their understanding and belief about formative assessment are likely to be influenced by CPD participation. CPD is an activity that is continuously performed by a teacher as an effort to improve professional competence (Alibakhshi \& Dehvari, 2015). Teachers' CPD provides experiences and builds capabilities that can influence the teaching practices and implementation of the assessment in the classroom. Theoretically, teachers with high CPD participation will have higher teaching knowledge, which affects their beliefs and practices. Their CPD participation intensity, therefore, influences their way of conducting the assessment (Andersson, Hellgren, \& Susanne, 2018). Teachers who have a strong belief in the importance of formative assessment would conduct formative assessments more appropriately. In other words, teachers' beliefs of formative assessment may have a substantial impact on the way assessment, and follow-up actions are carried out. However, the teachers' assessment practice, in some cases, may not be consistent with their beliefs.

The previous studies as described above indicated that teachers' beliefs of formative assessment influenced the implemetation of formative assessment. However, there was hardly any comprehensive study invistigated the phenomenon of teachers's beliefs viewed from their different level of CPD developement. This implies that more teachers should develop their skill in conducting formative assessment and should always consider factors which may influence the implemetation of formative assessment. 
Therefore, it is urgently important to conduct a study which deals with teachers' beliefs of formative assessment viewed from thier different CPD involment. Thus, the main objectives of this study are to identify the teachers' beliefs about formative assessment, to investigate how EFL teachers conduct their formative assessment practices related to their beliefs, and to find the relationship between CPD participation levels and EFL teachers' beliefs and practices.

\section{METHOD}

\section{Research Design}

Multi-case studies were carried to explore each case of the dissonance of teachers' beliefs and practices viewed from different teachers' CPD participation level. In short, using a multi-cases study to investigate selected cases, the cases can be compared in depth and describe and interpret the situational uniqueness of their cases from the same phenomenon through different perspectives beliefs (Borg, 2011). A qualitative approach was used to develop an understanding not only of what and how, but why teachers' beliefs are not consistent with their practices. Through qualitative research, empirical knowledge of teachers' beliefs and formative assessment practices in EFL classes can then be excessively revealed as the findings of this study.

\section{Participants}

There were some criteria for participant selection: having teaching qualifications and having at least five years of teaching experience. Having a minimum of bachelor's degree in English Education and representing intensity different CPD participation. There were 12 English teachers at the school where this study was condcuted. However Based on the selection creteria, there were only three teachers fulfill the creteria set prior to the study. Consequently, those three teachers were chosen as a sample of this study. The selected participats were teachers with different levels of CPD participation. They were from a high, average, and low CPD participation. They were coded as Ayu, Alit and Putu. The objective of this study was to compare the dissonance of the EFL teachers' beliefs and practices of formative assessment across different CPD participation level.

\section{Data Collection}

There were several techniques used to collect data, such as semi-structured interviews, observation, and document studies. Semi-structured interviews were used in gathering data related to beliefs about formative assessment and the dissonance between beliefs and practices across different CPD involvement level. There were three steps of interviews conducted in this study. The purpose of the first interview is to determine the understanding and pedagogical beliefs about formative assessment as well as how formative assessment is conducted in the classroom. The second interview was related to the practice of the participants in the class about the results of the previous interview. This interview was conducted in conjunction with classroom observation. The purpose of the third interview is to reveal the relationship between participants' beliefs about formative assessment and practice. Classroom observations were used to collect the data 
regarding formative assessment practices. Observations were conducted to reveal the dissonance between teachers' beliefs and practice of formative assessment. During classroom observations, notes on classroom activities were also taken. All activities were recorded and transcribed to facilitate analysis.

\section{Data Analysis}

In analyzing some cases, a detailed description of each formative assessment belief and the dissonance between teachers' beliefs and practices was provided thoroughly. The collected data were analyzed through interpretative analysis processes. The interview transcripts were supplemented with data obtained from the records at the time of observation. The collected data were transcribed and interpreted. Then the transcripts were checked to make sure all the required data has been recorded. The data transcripts were then returned to the participants to validate what they say. Interview data and observation data were coded and categorized by the specified category, which was then analysed argumentatively.

\section{FINDINGS}

This section aims at presenting the findings of the study, which lead to the answers to the research questions. These research questions are regarding: (1) The teachers' beliefs of formative assessment, (2) The EFL teachers' formative assessment practices related to their beliefs, (3) The relationship between CPD participation levels and the dissonances of EFL teachers' beliefs and practices.

\section{Teachers' Beliefs of Formative Assessment}

The finding concerning teachers' beliefs of formative assessment deals with beliefs of the purpose of formative assessment, beliefs in the impact of formative assessment on the teaching and learning, and beliefs in effects of formative assessment on students' learning; these findings are briefly discussed as follows.

\section{Beliefs of the purpose of formative assessment}

During the interviews, Putu explained that the primary purpose of conducting a formative assessment is to improve students' learning achievement. According to her, formative makes her students focus more on learning because students can see the extent of their understanding through formative assessment and their weaknesses in learning. She also explained that her students learned more intensively based on the feedback given and gain the learning goal and learning competence in a short period.

"The purpose of formative assessment is to improve students' learning. I believe that conducting formative assessment properly will help students in learning to achieve a higher level of ability because my students become focus more on learning. I also believe that formative assessment can help me to be more professional in teaching."

The excerpt of the interview above showed that Putu believed that formative assessment certainly helps her students in gaining higher competence when learning based on the 
results of the formative assessment. She also believed that formative assessment results help her to determine a better teaching strategy or modify her teaching style to accommodate her students' learning needs. Through continually trying to teach by her students' needs, she eventually becomes more professional in teaching if she is continually joining the CPD programs. Similarly, Alit believed that formative assessment could improve her students' learning achievement and also it can help him develop his teaching ability. This is one reason why he always planned and properly conducted the formative assessment.

"I think the purpose of formative assessment is to improve the students' learning and also to improve my teaching skill. I believe it can help my students and also help me to more professional in teaching."

The excerpt of the interview above showed that Alit has a strong belief that formative assessment certainly improves his students' learning achievement and also his teaching ability can be developed professionally based on the result of the formative assessment. On the other hand, Ayu has a considerably poor belief of formative assessment compared with Putu and Alit.

"I do not understand why we need to assess the students all the time. I usually ask them whether they understand or not at the end of the lesson. I am not sure how

formative assessment helps my students in learning."

The excerpt of the interview above showed that Ayu has very poor beliefs of formative assessment. She could not explain clearly why the formative assessment should be conducted in the classroom. Moreover, she did not have a sufficient understanding of the benefits of conducting the formative assessment.

Consequently, she did not conduct the formative assessment as stated by assessment guideline. She asked her students' understanding through questioning them. She described that by asking the students whether they understand or not is sufficient to check their understanding and easy to do is considered to be sufficiently effective.

\section{Beliefs in the impact of formative assessment on teaching and learning}

The usefulness of formative assessment is believed to have a considerable impact on the teaching and learning process. Formative assessment may create more conducive teaching, and learning atmosphere as some modification to learning strategies commonly used by the teachers have been done to suit the need of the students. Contextualization of teaching strategies is needed to be done in order that learning activities reflect the students' real condition.

"For me, formative assessment helps me determine my students' current learning progress. I prepare the formative assessment to the best of my ability and then I properly practice it in my classroom to improve the quality of teaching and to improve students' capacity to perform their skill in English. 
"I believe that formative assessment can enhance my teaching ability because it gives me a reflection on how successful I am teaching. I can then use the assessment result to modify my teaching strategy."

The excerpt showed that Putu creates high-quality formative assessment tasks to ensure that maximum assessment purposes achieved and during the instruction, she tried to conduct it properly to improve her teaching and enhance her teaching. The excerpt of the interview also showed that formative assessment has impacts on teaching strategy to meet the need of the students.

Alit is a teacher who is planned and implemented formative assessment in his class. He believes that formative assessment is a vital activity to do to enrich students' learning achievement.

"I believed that formative assessment could improve my teaching and also make my students more focus on their learning. My students learn English for intensively to achieve the goals of learning."

The excerpt of the interviews shows that Alit properly planned his formative assessment and implemented the formative assessment as what has been planned to see the students' achievement and to know the degree of learning goal attained by his students.

Ayu has different views on formative assessment. She believes that formative assessment merely for scoring and grading his students. The assessment is conducted to merely to measure the students' ability.

"I do not really believe that formative assessment can improve my teaching and learning process. I can see how I can improve my ability to modify my teaching strategies through formative assessment."

The excerpt showed that Ayu strongly disbelieved that formative assessment can improve teaching and learning practices. She seems uncertain about the benefits of formative assessment. Formative assessment is only conducted to find out the students' learning achievement. Additionally, she does not believe that she needs to modify her teaching style based on the formative assessment result.

\section{Beliefs in the effects of formative assessment on students' learning}

Putu believed in formative assessment usefulness in providing information about students' learning outcomes. She, therefore, properly plans and administers formative assessment implementation and makes use of the results for learning improvement. Feedback is always given in order that students learn based on the feedback to achieve the learning goal quicker.

Putu often gives oral feedback to the students' presentation and students' assignment publicly with expectation other students learn from their friends. Putu also makes an effort to give written feedback, although it is not usually optimally given due to time limitation. Besides time constraint encountered by Putu in giving feedback, she also has to teach too many sub-language competences. She consequently has to focus on giving 
oral feedback. She, however, realizes that feedback should always be given either written or orally. According to her that her students learn faster if feedback was given to her students' works.

"My students learn English more seriously after they know the result of their formative assessment. Their English gradually improve in each learning unit, which makes her end semester achievement is getting higher."

Alit also has similar views with Putu that formative assessment may improve students' learning in which students can learn from their weaknesses. Ayu, on the other hand, has different beliefs compared to Putu and Alit. She conducted an assessment at the end of the learning session merely to find out her students' ability. She did not make use of the result for students' learning improvement because she does not really believe that assessment result can be used to improve students' learning.

"I do not really believe that my students learn better after getting the assessment results. The assessment is only useful to see my students' ability."

The excerpt showed that Ayu conducted the formative assessment at the end of the learning session. Her purpose in conducting the formative assessment is only to see the students' achievement and grade her students. She usually did not make use of formative assessment result to improve her students learning because she has poor belief that formative assessment result would be useful for learning improvement.

\section{Teachers' Formative Assessment Practices and Their Beliefs}

Several classroom observations were conducted to reveal the teachers' formative assessment practices related to their beliefs as what has been described during the interviews. Before conducting classroom observation, document studies were also conducted to see the preparation made by the participants. All the participants wrote lesson plans which also contain the types of assessment. The planned the assessment according to their beliefs. During the classroom observation, Putu conducted the formative assessment at the end of the learning unit by administrating formative test concerning the learning topics previously presented. She asked her students to sit with about one-meter distance of separation to avoid the possibility of cheating. The administration of the assessment was strictly in an assessment condition, but the assessment atmosphere was really conducive in which students were allowed to ask Putu for test item clarification.

The classroom observation showed that Alit conducted the formative assessment conducted formative assessment strictly in which students were not allowed to chat with their friends and also the students were not allowed to consult with their books or classroom notes. The written assessments were in the form essay test, which required students to construct their answer using their own words. The assessment condition was seriously situated in which students were seated in the distance to each other to avoid cheating. Time allotment to answer the tests were strictly allocated. Alit, however, positioned himself as a test facilitator who was available to assist his students if any assistance in assessment provision was needed. Meanwhile, Putu conducted remedial 
teaching for his students with low ability. Remedial teaching was thoroughly carried out due to time allocation constraints. Alit, on the other hand, conducted remedial teaching to the students who were really below the learning standard. He prefers giving his students more exercises to do rather than giving remedial teaching as he is busy with administrative duties as an English teacher as well as a headmaster.

Putu administrated formative assessment strictly, and both of them also provide feedback to their students. Putu usually gave oral feedback based on her students' formative assessment results in the form of oral and written feedback. However, written feedback was occasionally given by Putu due to the limitation of time. Alit mainly focuses on giving oral feedback, and written feedback was hardly given. The written feedback given by Alit was rather general and written in very short remarks stating "poor, sufficient, good, and excellent". These qualitative wordings were not sufficient for the students, as these words were more usable for grading. Ayu conducted the formative assessment in a more relaxed situation. She distributed the test and asked her students to answer them individually. During the assessment process, she walked around the class and occasionally told her students in order not to work together. She made sure her students work by themselves because her aim of giving formative assessment is to grade her students. She did not plan for remedial teaching for her students whose poor ability for the learning unit being assessed.

The relationship between CPD involvement levels and the dissonance of belief and practices of formative assessment

The study indicates that teachers in this study have different levels of CPD involvement, which influenced their formative assessment practices.

"I attended many CPD programs, which provides me with sufficient knowledge of how I should conduct the classroom assessment properly."

The excerpt showed that Putu has quite high CPD participation and very experienced teacher. Her knowledge and beliefs about the importance of formative assessment are very high. She planned the formative assessment properly based on the learning objective in order she knew, and the students also knew the accomplishment of the learning objectives at the end of each learning unit. Additionally, she also conducted the formative assessment as she planned in a favorable condition to ensure her students can provide the answers to the tests accordingly. However, based on the observation, Putu did not intensively conduct the follow-up action. During the remedial teaching, she repeated the lessons that she thought the students need to learn to make them understand. When her students still could not understand, she simply asked the students to do more exercises as homework. She was reluctant to spend more time to deliver the lessons using a better way of learning.

"having many teaching experiences and having a good CPD involvement help me to conduct the formative assessment in the classroom appropriately."

The excerpt showed that Alit also has good CPD participation and long teaching experiences. However, during the formative assessment, he improperly conducted it. 
Feedback was not properly given by Alit. He did not give feedback to all students because he had very limited time. The follow-up actions conducted by Alit were mainly in the form of remedial teaching for his students who had a really low ability on particular learning material. He did this because he did not have enough time to give remedial teaching to all students. He also used the same strategy in giving remedial teaching in which she made use of questioning strategy as a learning process. He did this because he believed that is the best way of teaching. Additionally, he was not willing to try another technique which is more innovative and challenging for the students.

"well, I do not often have the opportunity to join the CPD program. I mainly relied on my knowledge that I gained from my college and from the experiences I obtained when I did my teaching practices."

The excerpt showed that Ayu could be considered as a new teacher who works merely based on her knowledge attained from her education college. She has very low CPD participation. Consequently, her understanding of language assessment is also very low. She conducted teaching and learning process based on learning syllabus, and by incorporating her university knowledge and three months teaching practice, she gained from her university when she studied in the faculty understood the purpose of conducting the formative assessment in the classroom. She, therefore, had low knowledge about formative assessment. Consequently, she did not properly conduct the formative assessment.

\section{DISCUSSION}

Learning activities can be appropriately designed by utilizing the results of students' assessment (Yahiji et al., 2019). Formative assessment, in particular, is really important for both students and teachers. The result of formative assessment can be used to design learning sequences and learning activities more effectively (Karim, 2015). Through understanding the results of the formative assessment, teachers then can use it to revise their teaching strategy to be more effective teaching strategy by doing a modification to the teaching strategy being used (Birenbaum et al., 2011). The success of formative assessment practices is much influenced by their beliefs. Teachers who have strong beliefs normally properly practiced formative assessment as well as using the results of the formative assessment as the basis of learning improvement and teachers' teaching improvement. Conducting formative assessment enables teachers to provide corrective feedback relevantly to the learning objective to be achieved by the students (Black \& Wiliam, 2009). Additionally, teachers then can appropriately plan their follow up actions to improve students' learning. Moreover, Kuze \& Shumba (2011) suggests that if it is necessary, teachers then can modify their teaching style to suit the need of the students and students' learning condition.

As described above that belief of teachers is a key success of formative assessment implementation. Beliefs are generally formed through personal experiences and interactions in daily life and interpretations of events individuals have engaged in. In educational contexts, this concept of belief system governs teaching behavior, with individual pedagogies reflecting a teacher's beliefs about language teaching. Teachers' 
thought processes and instructional decisions are influenced by their beliefs (Borg, 2011). This study was conducted to the EFL teachers in different CPD involvement uncover the back shield of actual formative assessment implementation in which teachers from different CPD level has different belief in formative assessment and CPD involvement impacted the way teachers perceive formative assessment (Alibakhshi \& Dehvari, 2015; Andersson et al., 2018), Teachers' formative assessment practices, however, were not strongly impacted by different level of CPD involvement. This phenomenon occurred during the present study in which in cases of Putu and Alit. Both of them have considerably strong beliefs and CPD involvement. However, their formative assessment practices were not in line with their beliefs and CPD.

It was found that Putu conducted a formative assessment in contrary to her belief and CPD involvement. Putu is had high CPD involvement and has a strong belief in formative assessment. She did not, however, conduct formative assessment perfectly as characterized by the good practice of formative assessment. It was found that written feedback was not always given to the student. She predominantly provides oral feedback which given publicly. In addition to that manner, she did not usually provide intensive remedial teaching as a follow-up action. She did a follow-up action in the form of remedial teaching, but she did not do any recheck whether all her students achieved the learning objective or not. Consequently, she did not get a clear overall refection about her students' ability and passing grade achievement. Similarly, Alit is a teacher with medium CPD involvement level, and considerable long teaching experience found that he did not carry out formative assessment properly, he made quite sufficient planning and conducted a formative assessment, he did not however intensively organized and conducted the follow-up action. He often just gave more exercises to do at home for those who have low achievement. Remedial teaching was only arranged for the students who are really below the learning criterion standard.

The goal of professional development is to enhance teachers' practices. All the impact of CPD is primarily based on mere assumption or beliefs; their finding cannot provide the answer on how much CPD can change their real practice. In this teacher, ' professional development also influences the implementation of formative assessment in the classroom. As found in some studies that English teachers should be able to carry out the formative assessment by their beliefs about formative assessment. The suitability is found when the teacher performs a formative assessment appropriately. The teachers in this study gave some types of test in conducting a formative assessment, and they also provided feedback about the students' achievement. They also found some obstacles encountered by the students in learning, but they did not use the result of the assessment for learning improvement and modifying their teaching strategy. Putu and Alit have good beliefs of formative assessment. However, they did not do follow up action maximally. This study showed that the difference between CPD involvement level at teacher does not affect the consonant between belief and their practice. This can be caused by the lack of good motivation for the teacher to be able to carry out follow up the action well. 
Ayu was found that she did not really make use of formative assessment result for learning improvement. She simply considered that formative assessment is a routine assessment that should be conducted as a part of the teaching process to measure her students' ability. She did not really comprehend the benefits of formative assessment for learning and teaching improvement. It is due to Ayu hardly had CPD participation as she is a new English teacher with considerably low ability in English language teaching. Therefore, it can be said that Ayu has totally different views of formative assessment practices compared with Alit and Putu. This is because they all have different CPD involvement which also influence their beliefs of formative assessment practices.

The findings above were really in contrast with the previous finding concerning the relationship between continuing professional development and teachers' beliefs and practices with found that the teacher with high CPD involvement level has strong and good beliefs on the purpose of formative assessment. This is due to the experience and good knowledge they have. However, teachers with low-level CPD involvement have less belief in the benefits and objectives of formative. It has an impact on the implementation of formative assessments by teachers in the classroom assessment (Borg, 2011; Quyen \& Khairani, 2016).

The present study which dealt with teachers' beliefs in formative assessment practices viewed from teachers' different CPD involvement revealed that higher teachers' CPD involvement has a higher belief in the formative assessment that can improve teaching and learning, but these beliefs were not continued in the follow-up action in which even higher teachers' CPD involvement did not carry out properly the follow-up actions. Differences in CPD involvement levels do not really affect the implementation of follow-up actions by teachers in the classroom. Therefore, this study proved that there are several dissonances of EFL teachers' beliefs in formative assessment and the implementation of their practice of formative assessment and the dissonances are much influenced by the intensity and the level of teachers' CPD involvement. Considering the findings of this study as described above, therefore, it is expected that the finding provide valuable significance to EFL teachers to conduct more appropriate formative assessment and related education stakeholders may use this finding for further development programs concerning teachers' CPD development and formative assessment practices.

\section{CONCLUSION}

Formative assessment is considered to be a highly effective way to find out the students' problems in learning. Teachers can make use of formative assessment results as a basis for teaching and learning improvement. It enables teachers to continually modify their teaching practices. Teachers are then expected to have high beliefs in formative assessment and appropriately carried out their beliefs in formative assessment administration. This study describes the dissonances of teachers' beliefs and practices of formative assessment practices viewed from different CPD involvement. It was found that the teachers with different CPD participation have different intensity of formative assessment implementation. The teachers with high CPD participation do not always perform their formative assessment practice as what they beliefs about the benefit of 
conducting the formative assessment in the classroom. On the other hands, teachers with low CPD involvement did not always conduct poor formative assessment. This study revealed that High or low CPD involvement indirectly influenced the appropriate implementation of formative assessment. There are other factors may have stronger influences such as time allocation, teachers' workload, and classroom condition. Although this study has been conducted intensively and the data was thoroughly analyzed, the findings of this study should be carefully generalized due to limited samples being investigated. Therefore, further studies are recommended to be conducted by other researchers to reveal further findings related to teachers' formative assessment practices.

\section{ACKNOWLEDGEMENT}

The author would like to thank the Indonesian Directorate General of Higher Education, the Ministry of Research, Technology and Higher Education for all research grants and funding to conduct this study, Universitas Negeri Malang, and the Faculty of Teacher Training and Education of Mahasaraswati Denpasar University for the valuable supports during conducting this study.

\section{REFERENCES}

Alibakhshi, G., \& Dehvari, N. (2015). EFL teachers' perceptions of continuing professional development: A case of Iranian high school teachers. PROFILE Issues in $\begin{array}{llll}\text { Teachers' } & \text { Professional } & \text { 29-42. }\end{array}$ https://doi.org/10.15446/profile.v17n2.44374.

Andersson, P., Hellgren, M., \& Susanne, K. (2018). Factors influencing the value of CPD activities among VET Teachers. International Journal for Research in Vocational Education and Training, 5(2), 140-164. https://doi.org/10.13152/IJRVET.5.2.4.

Ashraf, H., \& Zolfaghari, S. (2018). EFL Teachers' assessment literacy and their reflective teaching. International Journal of Instruction, 11(1), 425-436. https://doi.org/10.12973/iji.2018.11129a.

Birenbaum, M., Kimron, H., \& Shilton, H. (2011). Nested contexts that shape assessment for learning: School-based professional learning community and classroom culture. Studies in Educational Evaluation, 37(1), 35-48. https://doi.org/10.1016/j.stueduc.2011.04.001.

Black, P., \& Wiliam, D. (2009). Developing the theory of formative assessment. Educational Assessment, Evaluation and Accountability, 21(1), 5-31. https://doi.org/10.1007/s11092-008-9068-5.

Borg, S. (2011). The impact of in-service teacher education on language teachers' beliefs. System, 39(3), 370-380. https://doi.org/10.1016/j.system.2011.07.009.

Box, C., Skoog, G., \& Dabbs, J. M. (2015). A case study of teacher personal practice assessment theories and complexities of implementing formative assessment. American Educational Research Journal, 52(5), 956-983. https://doi.org/10.3102/0002831215587754.

Clark, I. (2012). Formative assessment: A systematic and artistic process of instruction 
for supporting school and lifelong learning. Canadian Journal of Education, 35(2), 2440. https://doi.org/10.1007/s10648-011-9191-6.

Coffey, J. E., Hammer, D., Levin, D. M., \& Grant, T. (2011). The missing disciplinary substance of formative assessment. Journal of Research in Science Teaching, 48(10), 1109-1136. https://doi.org/10.1002/tea.20440.

Derrick, J., \& Ecclestone, K. (2006). Formative assessment in adult literacy, language and numeracy programmes: A literature review for the OECD. DRAFT.

Guadu, Z. B., \& Boersma, E. J. (2018). EFL instructors' beliefs and practices of formative assessment in teaching writing. Journal of Language Teaching and Research, 9(1), 42-50. https://doi.org/10.17507/jltr.0901.06.

Karim, B. H. H. (2015). The impact of teachers' beliefs and perceptions about formative assessment in the university ESL class. International Journal of Humanities, Social Sciences and Education, 2(3), 108-115.

Karimi, M. N., \& Shafiee, Z. (2014). Iranian EFL teachers' perceptions of dynamic assessment: Exploring the role of education and length of service. Australian Journal of Teacher Education, 39(8), 143-162. https://doi.org/10.14221/ajte.2014v39n8.10.

Kuzborska, I. (2011). Links between teachers' beliefs and practices and research on reading. Reading in a Foreign Language, 23(1), 102-128.

Kuze, M. W., \& Shumba, A. (2011). An Investigation into formative assessment practices of teachers in selected schools in fort beaufort in South Africa. Journal of Social Sciences, 29(2), 159-170. https://doi.org/10.1080/09718923.2011.11892966.

Leung, C., \& Scott, C. (2009). Formative assessment in language education policies: Emerging lessons from Wales and Scotland. Annual Review of Applied Linguistics, 29, 64-79. https://doi.org/10.1017/S0267190509090060.

Pantiwati, Y., \& Husamah (2017). Self and peer assessments in active learning model to increase metacognitive awareness and cognitive abilities. International Journal of Instruction, 10(4),185-202. https://doi.org/10.12973/iji.2017.10411a.

Quyen, N. T. D., \& Khairani, A. Z. (2016). Reviewing the challenges of implementing formative assessment in Asia: The need for a professional development program. Journal of Social Science Studies, 4(1), 160-177. https://doi.org/10.5296/jsss.v4i1.9728.

Rivai, E., Ridwan, A., Supriyati, Y., \& Rahmawati, Y. (2019). Influence of test construction knowledge, teaching material and attitude on sociological subject to quality of objective test in public and private vocational schools. International Journal of Instruction, 12(3),497-512. https://doi.org/10.29333/iji.2019.12330a.

Stiggins, R. J. (2002). Assessment crisis: The absence of assessment for learning. Phi Delta Kappan, 83(10), 1-10.

Yahiji, K., Otaya, L. G., \& Anwar, H. (2019). Assessment model of student field practice at faculty of tarbiyah and teaching training in Indonesia: A reality and expectation. International Journal of Instruction, 12(1), 251-268. https://doi.org/10.29333/iji.2019.12117a. 